\title{
ANALISIS TEKNO EKONOMI PEMANFAATAN LIMBAH BUAH-BUAHAN SEBAGAI MIKRO ORGANISME LOKAL (MOL)
}

\author{
Muhammad Nur \\ Alfinur Khairi \\ UIN Sultan Syarif Kasim Riau \\ Muhammad.nur@uin-suska.ac.id
}

\begin{abstract}
The high volume of garbage in the city of Pekanbaru, especially organic garbage, has led to the idea of utilizing the garbage to become a more useful thing, where it can be used as material in making MOL (local organism). The utilization of MOL (local organism) it self is very beneficial for farmers because the ingredients that used come from the organic materials, and the costs that we used are less than buying commercial fertilizers.The purpose of this study is to find out the process of making MOL, to know the nutrient test values in MOL from the waste of fruits, to know the techno-economics of making MOL from the waste of fruits. The method that used is Variable Costing to calculate The Cost of Production and the Random Duplicate Design method to determine the treatment of MOL. The results of the laboratory test showed that Treatment A on the 3rd repetition with a level of $100 \mathrm{ml}$ EM-4 had the best results with a value of Nitrogen 0.0010\%, Fospor 0.000014\%, and Potassium 0.000022\%. The cost of production is Rp 21,000 / Liter and Break Even Point is 4 Liter that relased in Rp 69,686.49.
\end{abstract}

Keywords : Break Event Point, The cost of production, Local Organism, Random Duplicate Design, Garbage.

\section{PENDAHULIAN}

Akibat dari banyaknya peredaran buahbuahan di Pekanbaru menyebabkan tingginya volume sampah dari sisa buah-buahan. Permasalahan sampah di Pekanbaru hingga saat ini masih belum dapat diselesaikan secara optimal, hal ini dikarenakan rendahnya tingkat kesadaran masyarakat terhadap pengolahan sampah. Dampak dari sampah itu sendiri menyebabkan berbagai persoalan seperti timbulnya penyakit, polusi udara, polusi air dan lain sebagainya.

Jumlah limbah buah-buahan pada tahun 2017 adalah 13.091,016 ton/tahun. Hingga saat ini belum ada pemanfaatan limbah buahbuahan dari masyarakat sehingga mengakibatkan banyaknya tumpukan sampah yang bisa mencemari lingkungan, akan tetapi berdasarkan penelitian sebelumnya ada beberapa limbah buah-buahan yang dimanfaatkan menjadi pupuk organik seperti limbah tomat, limbah buah jambu biji, limbah pisang, limbah pepaya dan limbah kulit nanas.

Limbah buah-buahan itu sendiri bisa dimanfaatkan menjadi pupuk organik, karena limbah buah-buahan memiliki kandungan Nitrogen (N), Fospor (P), Kalium (K), Vitamin, Kalsium (Ca), Zat besi (Fe), Natrium $(\mathrm{Na})$, Magnesium $(\mathrm{Mg})$ dan lain sebagainya. Kandungan yang ada pada limbah buahbuahan sangat berguna bagi kesuburan tanah, sehingga sangat cocok untuk dijadikan pupuk organik maupun mikro organisme lokal (Marjenah, 2017).

Mikroorganisme Lokal (MOL) adalah cairan hasil fermentasi dari substrat atau media tertentu yang berada di sekitar kita 


\section{MUHAMMAD NUR, ALFINUR KHAIRI \\ Analisis Tekno Ekonomi Pemanfaatan Limbah Buah-Buahan Sebagai Mikro Organisme Lokal (Mol)}

(misalnya nasi, buah-buahan, telur, susu, keong dan lain-lain). MOL dapat juga diartikan mikroorganisme yang berasal dari substrat/bahan tertentu dan diperbanyak dengan bahan alami yang mengandung karbohidrat (gula), protein, mineral dan vitamin. MOL berfungsi sebagai penyubur media tanam, berbeda dengan pupuk cair yang menyuburkan tanaman (Badan Penelitian dan Pengembangan Pertanian Kementrian Pertanian, 2015).

Penelitian pemanfaatan limbah buahbuahan sebagai mikroorganisme lokal (MOL) ini perlu dilakukan dikarenakan pembuatan MOL dapat mengurangi jumlah volume sampah yang menumpuk di Pekanbaru. Pembuatan MOL sangat menguntungkan petani karena bahan yang digunakan berasal dari bahan-bahan organik, serta biaya yang dikeluarkan lebih sedikit dibandingkan dengan membeli pupuk komersial. Selain itu agar layak digunakan oleh masyarakat perlu diadakan suatu analisa tekno ekonomi untuk mengetahui keuntungan apabila MOL ini diproduksi dan dipasarkan sebagai inovasi terbaharukan dari pupuk komersial yang beredar dipasaran. Rumusan masalah pada penelitian ini adalah bagaimana analisis tekno ekonomi pemanfaatan limbah buah-buahan sebagai mikro organisme lokal (MOL), dengan tujuan penelitian untuk mengetahui bagaimana proses pembuatan mikro organisme lokal (MOL) dari limbah buahbuahan, untuk melihat hasil uji unsur hara dalam mikro organisme lokal (MOL) dari limbah buah-buahan, untuk mengetahui tekno ekonomi pembuatan mikro organisme lokal (MOL) dari limbah buah-buahan.

\section{REVIEW LITERATUR}

\section{Rancangan Acak Lengkap}

Menurut Mery Siska yang dikutip dalam

Sudjana 1994, rancangan acak lengkap diartikan sebagai suatu eksperimen dimana hanya mempunyai sebuah faktor yang nilainya berubah-ubah. Faktor yang diperhatikan dapat memiliki sejumlah taraf dengan nilai yang bisa kuantitatif, kualitatif, bersifat tetap ataupun acak. Pengacakan dalam eksperimen yang dilakukan tidak ada pembatasan, dalam hal demikian diperoleh desain pengacakan yang dilakukan secara lengkap atau sempurna yang biasa disebut desain rancangan acak lengkap (RAL).

\section{Harga Pokok Produksi}

Harga pokok merupakan pengorbanan sumber ekonomi untuk memperoleh aktiva. Menurut Mulyadi (2002) dalam Bakhtiar (2012) harga pokok digunakan untuk menunjukkan pengorbanan sumber ekonomi dalam pengolahan bahan baku menjadi produk. Menurut Hansen dan Mowen (2001) yang diterjemahkan oleh Ancella A. Hermawan M.B.A (2006) dikutip oleh Bakhtiar (2012) menyatakan bahwa harga pokok produksi mencerminkan total biaya barang yang diselesaikan selama periode berjalan. Biaya yang hanya akan dibebankan ke barang yang diselesaikan adalah biaya manufaktur bahan langsung, biaya tenaga kerja langsung dan overhead. Rincian dari biaya ini diuraikan dalam daftar pendukung yang disebut sebagai laporan harga pokok produksi (Bakhtiar, 2012). Biaya overhead variable pada metode variable costing seperti penggunaan air dan listrik. Adapun rumus menghitung biaya pemakaian listrik sebagai berikut (Purbaningrum, 2014):

Total daya dalam sehari Kwh:

$\mathrm{W}=\frac{\mathrm{Pxt}}{1000}$.

Biaya yang harus dibayar:

Biaya = Jumlah Energi Kwh x Tarif per Kwh.

Keterangan:

$\mathrm{W}=$ energy yang dibutuhkan (Joule)

$\mathrm{P}$ = daya yang dibutuhkan (watt)

$\mathrm{t}$ = waktu yang dibutuhkan (sekon)

Untuk menentukan harga pokok per unit produsi perunit dapat dilihat pada Rumus sebagai berikut (Setiadi, 2014): 


\section{Harga Pokok Per Unit = Total Biaya \\ $\overline{\text { Jumlah produkyang di hasilkan }}$}

.............................. (3)

Harga Jual Produk dapat dilihat pada rumus berikut (Setiadi, 2014):

$$
\underset{\text { Harga Jual }}{\text { Jayal }} \text { Produk }
$$

\section{Break Even Point}

Break Even Point (BEP) adalah suatu keadaan di mana dalam operasi perusahaan, perusahaan itu tidak memperoleh laba dan tidak menderita rugi. Analisis pulang pokok atau analisis impas (analisis break event) adalah teknik analisis untuk mempelajari hubungan antar biaya, laba dan volume penjualan (Harjito, 2012).

Adapun rumus menentukan nilai break event point adalah sebagai berikut (Sabrin, 2015):

$\mathrm{BEP}($ unit $)=$

\section{Biaya Tetap}

Harga jual per unit-variabel per unit

$$
\operatorname{BEP}(\mathrm{Rp})=\frac{\text { Biaya Tetap }}{1-\text { Biaya variabel } / \text { penjualan }}
$$

\section{METODE PENELITIAN}

Metodologi penelitian merupakan tahapan-tahapan yang harus dilakukan peneliti secara jelas dan sistematis sebelum melakukan penelitian, mulai dari pengumpulan data sampai dengan kesimpulan. Adapun tahapan penelitian adalah sebagai berikut:

\section{Gambar 1.}

\section{Flowchart Metodologi Penelitian}

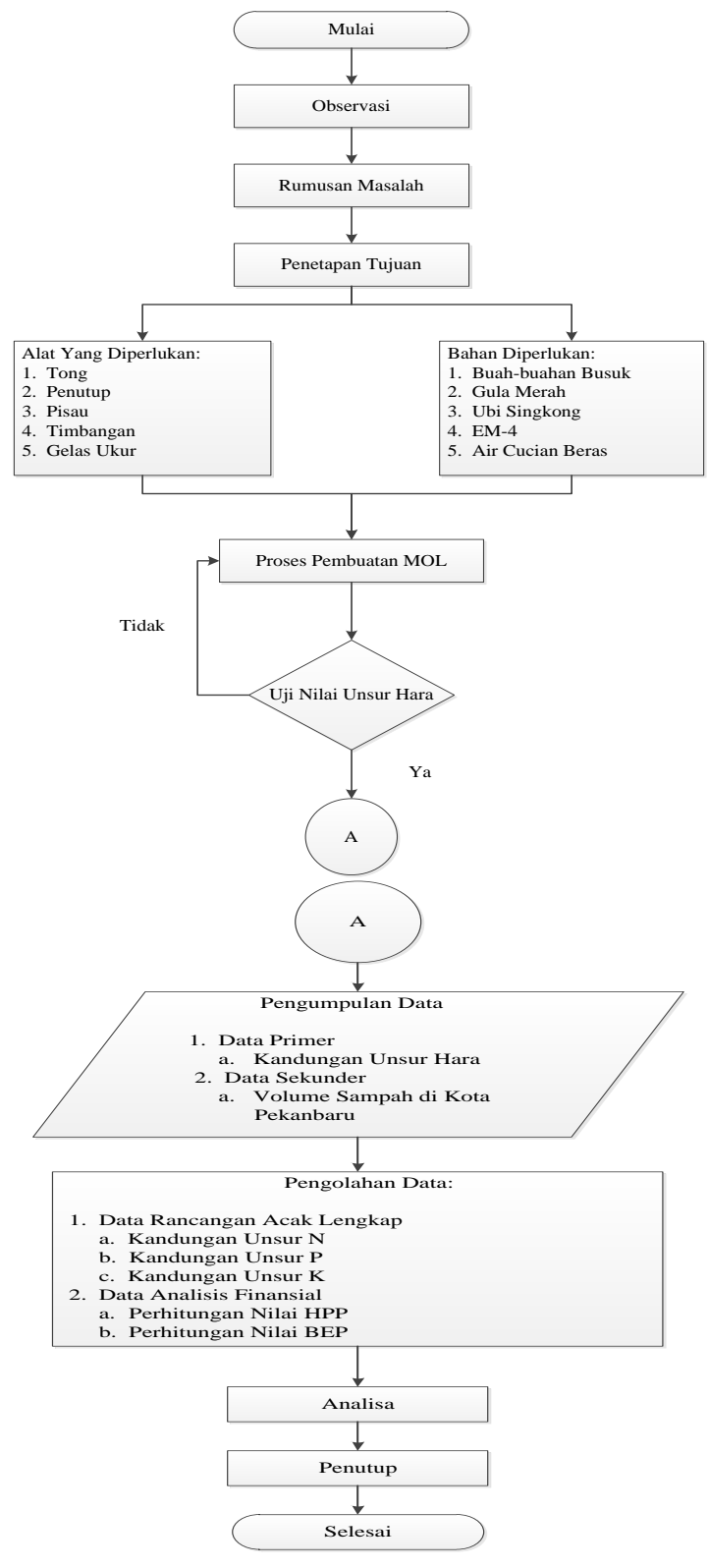

HASIL PENELITIAN DAN PEMBAHASAN

Pembuatan MOL dengan Menggunakan Metode RAL, Serta Perhitungan Tekno Ekonomi.

\section{A. Peralatan dan Bahan Penelitian}

1. Alat:

a. Tong digunakan sebagai wadah pada pembuatan MOL.

b. Penutup digunakan untuk menutup tong agar tidak ada udara yang masuk kedalam. 
c. Pisau digunakan sebagai alat untuk mencincang bahan baku.

d. Timbangan digunakan sebagai alat ukur berat bahan baku.

e. Gelas ukur digunakan sebagai alat ukur volume air cucian beras dan EM-4.

2. Bahan:

a. Limbah Buah-buahan diperoleh dari pasar kodim.

b. Gula Merah.

c. Ubi Singkong.

d. Cairan EM-4 digunakan sebagai pengurai yang dapat membantu dalam pembusukan. Pada penelitian ini kadar EM-4 yang digunakan dibedakan menjadi 4 perlakuan, yaitu: $100 \mathrm{ml}, 150 \mathrm{ml}$, $200 \mathrm{ml}$, dan $250 \mathrm{ml}$.

e. Air Cucian Beras.

\section{B. Proses Pembuatan MOL}

1. Proses penimbangan limbah buahbuahan, gula merah dan ubi singkong.

Proses penimbangan bertujuan untuk mengetahui kadar bahan baku dalam proses pembuatan MOL. Pada penelitian ini diadakan uji coba dengan menggunakan $4 \mathrm{~kg}$ limbah buah-buahan, $1 / 4 \mathrm{~kg}$ gula merah, 1/2 kg ubi singkong.

\section{Gambar 2.}

(a) Penimbangan Limbah Buah (b) Penimbangan Gula Merah (c) Penimbangan Ubi Singkong

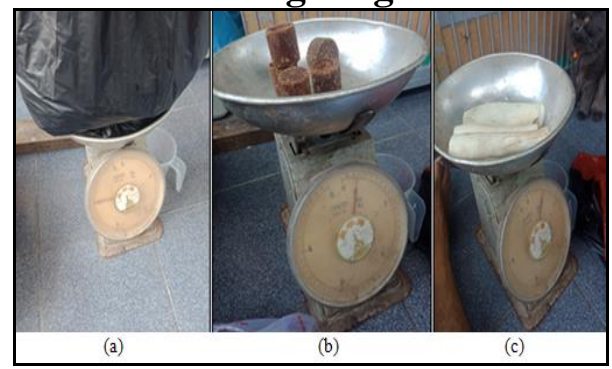

2. Proses penghalusan limbah buahbuahan
Limbah buah-buahan yang telah didapat dihaluskan terlebih dahulu. Bisa dengan cara ditumbuk, diparut atau dicincang halus.

Gambar 3.

Proses penghalusan limbah Buahbuahan

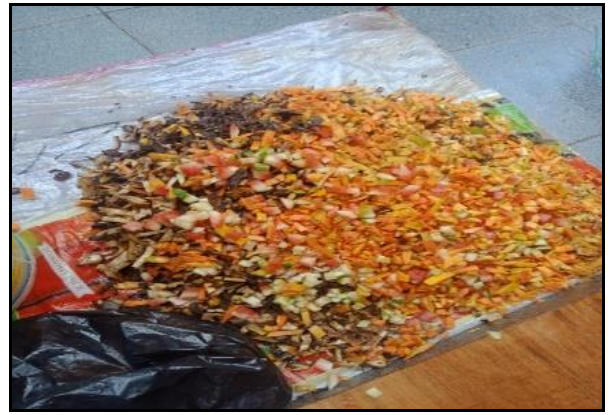

3. Proses pemotongan ubi singkong Ubi singkong yang sudah disiapkan dipotong terlebih dahulu. Bisa dengan cara dicincang atau diparut.

Gambar 4.

Proses Pemotongan Ubi Singkong

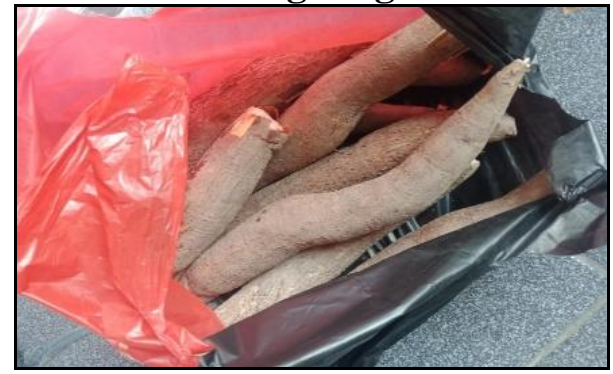

4. Pencampuran bahan

Bahan yang sudah dipotong dan dihaluskan kemudian dimasukkan kedalam tong, kemudian tambahkan 4 liter air cucian beras kedalamnya. Adapun pencampuran kadar cairan EM-4, limbah buah-buahan, gula merah, ubi singkong, dan air cucian beras dibedakan atas 4 perlakuan yakni:

a. MOL dengan kadar $100 \mathrm{ml}$ cairan EM-4, $4 \mathrm{~kg}$ limbah buah-buahan, 
$1 / 4 \mathrm{~kg}$ gula merah, $1 / 2 \mathrm{~kg}$ ubi singkong dan 4 liter air cucian beras.

b. MOL dengan kadar $150 \mathrm{ml}$ cairan EM-4, $4 \mathrm{~kg}$ limbah buah-buahan, $1 / 4 \mathrm{~kg}$ gula merah, $1 / 2 \mathrm{~kg}$ ubi singkong dan 4 liter air cucian beras.

c. MOL dengan kadar $200 \mathrm{ml}$ cairan EM-4, 4 kg limbah buah-buahan, $1 / 4 \mathrm{~kg}$ gula merah, $1 / 2 \mathrm{~kg}$ ubi singkong dan 4 liter air cucian beras.

d. MOL dengan kadar $250 \mathrm{ml}$ cairan EM-4, 4 kg limbah buah-buahan, $1 / 4 \mathrm{~kg}$ gula merah, $1 / 2 \mathrm{~kg}$ ubi singkong dan 4 liter air cucian beras.

\section{Gambar 5.}

Pencampuran

Bahan

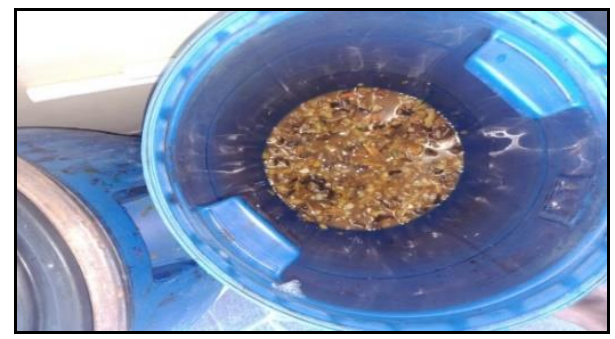

5. Proses pengadukan

Pada proses ini semua bahan-bahan yang sudah dicampurkan tadi diaduk sampai tercampur merata selama 3-5 menit.

Gambar 6.

Proses

Pengadukan

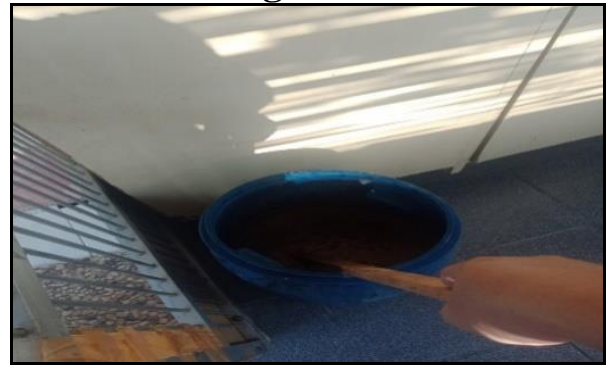

6. Proses penyimpanan

Pada proses ini semua bahan kemudian disimpan atau difermentasi pada wadah tertutup selama 2 minggu di tempat teduh. Wadah dilubangi dan diberi selang untuk mengeluarkan panas pada proses fermentasi.

Gambar 7.

Proses

Penyimpanan

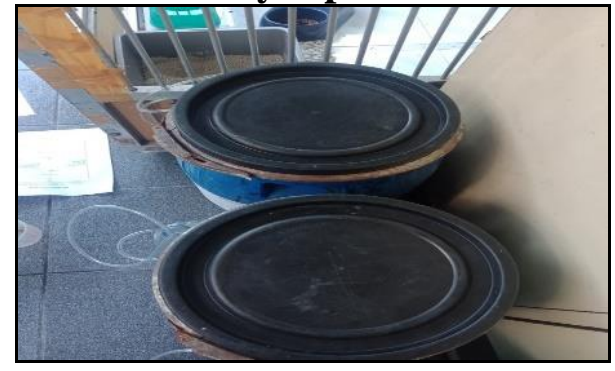

\section{Data Rancangan Acak Lengkap}

Pengujian kadar nilai N (Nitrogen), kadar dilai P (Fosfor), dan kadar nilai $\mathrm{K}$ (Kalium) di lakukan di Laboratorium Dinas Pekerjaan Umum dan Tata Ruang Povinsi Riau. Berikut ini adalah data hasil uji Nitrogen $(\mathrm{N})$ :

\section{Tabel 1.}

Data Uji Nitrogen (N)

\begin{tabular}{|c|c|c|c|c|c|}
\hline No & Sampel & $\begin{array}{c}\mathrm{ml} \\
\text { Sampel }\end{array}$ & $\begin{array}{c}\text { Pengulangan } \\
\text { ke- }\end{array}$ & $\begin{array}{c}\% \\
\text { Nitrogen }\end{array}$ & Standar \\
\hline 1 & A & $100 \mathrm{ml}$ & 2 & $0,11 \%$ & $<5 \%$ \\
\hline 2 & B & $100 \mathrm{ml}$ & 2 & $0,109 \%$ & $<5 \%$ \\
\hline 3 & $\mathrm{C}$ & $100 \mathrm{ml}$ & 2 & $0,26 \%$ & $<5 \%$ \\
\hline 4 & $\mathrm{D}$ & $100 \mathrm{ml}$ & 2 & $0,31 \%$ & $<5 \%$ \\
\hline
\end{tabular}

Dari Tabel diatas dapat dilihat bahwa kandungan nitrogen pada sampel D lebih tinggi dari sampel $\mathrm{A}, \mathrm{B}$, dan $\mathrm{C}$ dengan persentase $0,0029 \%$, dan kandungan nitrogen pada sampel A lebih rendah dari sampel $\mathrm{B}, \mathrm{C}$, dan $\mathrm{D}$ dengan persentase $0,0010 \%$. Artinya kandungan unsur nitrogen pada setiap perlakuan memenuhi standar.

Berikut ini adalah data hasil uji Fosfor (P): 
MUHAMMAD NUR, ALFINUR KHAIRI

Analisis Tekno Ekonomi Pemanfaatan Limbah Buah-Buahan Sebagai Mikro Organisme

Lokal (Mol)

Tabel 2.

Data Uji Fospor (P)

\begin{tabular}{|c|c|c|c|c|c|}
\hline No & Sampel & $\begin{array}{c}\mathrm{ml} \\
\text { Sampel }\end{array}$ & $\begin{array}{c}\text { Pengulangan } \\
\text { ke- }\end{array}$ & $\begin{array}{c}\% \\
\text { Fosfor }\end{array}$ & Standar \\
\hline 1 & A & $100 \mathrm{ml}$ & 2 & $0,0162 \%$ & $<5 \%$ \\
\hline 2 & B & $100 \mathrm{ml}$ & 2 & $0,014 \%$ & $<5 \%$ \\
\hline 3 & C & $100 \mathrm{ml}$ & 2 & $0,015 \%$ & $<5 \%$ \\
\hline 4 & D & $100 \mathrm{ml}$ & 2 & $0,0165 \%$ & $<5 \%$ \\
\hline
\end{tabular}

Dari Tabel diatas dapat dilihat kandungan fosfor tertinggi terdapat pada sampel D dengan persentase $0,000016 \%$, dan yang terendah pada sampel B dengan persentase $0,000014 \%$. Artinya kandungan unsur fosfor pada setiap perlakuan memenuhi standar.

Berikut ini adalah data hasil uji Kalium (K):

Tabel 3.

Data Uji Kalium (K)

\begin{tabular}{|c|c|c|c|c|c|}
\hline $\begin{array}{c}\text { N } \\
\text { o }\end{array}$ & $\begin{array}{c}\text { Samp } \\
\text { el }\end{array}$ & $\begin{array}{c}\mathrm{ml} \\
\text { Samp } \\
\text { el }\end{array}$ & $\begin{array}{c}\text { Pengulang } \\
\text { an ke- }\end{array}$ & $\begin{array}{c}\% \\
\text { Kaliu } \\
\mathrm{m}\end{array}$ & $\begin{array}{c}\text { Standa } \\
\mathrm{r}\end{array}$ \\
\hline 1 & $\mathrm{~A}$ & $\begin{array}{c}100 \\
\mathrm{ml}\end{array}$ & 3 & $\begin{array}{c}0,025 \\
\%\end{array}$ & $<5 \%$ \\
\hline 2 & $\mathrm{~B}$ & $\begin{array}{c}100 \\
\mathrm{ml}\end{array}$ & 3 & $\begin{array}{c}0,022 \\
\%\end{array}$ & $<5 \%$ \\
\hline 3 & $\mathrm{C}$ & $\begin{array}{c}100 \\
\mathrm{ml}\end{array}$ & 3 & $\begin{array}{c}0,022 \\
\%\end{array}$ & $<5 \%$ \\
\hline 4 & $\mathrm{D}$ & $\begin{array}{c}100 \\
\mathrm{ml}\end{array}$ & 3 & $\begin{array}{c}0,027 \\
\%\end{array}$ & $<5 \%$ \\
\hline
\end{tabular}

Dari Tabel diatas dapat dilihat bahwa sampel D memiliki kandungan kalium tertinggi dengan persentase $0,000030 \%$, dan sampel A memiliki kandungan kalium terendah dengan persentase $0,000022 \%$. Artinya kandungan unsur kalium pada setiap perlakuan memenuhi standar. Pada penelitian ini dapat dilihat bahwa limbah buah-buahan bisa dijadikan MOL.

\section{Perhitungan Harga Pokok Produksi}

Biaya-biaya yang dikeluarkan pada pembuatan MOL dengan menggunakan metode variable costing yang dapat dilihat pada Tabel berikut:
Tabel 4.

Rekapitulasi Biaya Variabel Pembuatan Pupuk Organik Cair

\begin{tabular}{|c|l|c|}
\hline No & \multicolumn{1}{|c|}{ Variable Costing } & Harga Perhari (Rp) \\
\hline 1 & Biaya Bahan Baku & 9.300 \\
\hline 2 & Biaya Tenaga Kerja & 60.000 \\
\hline 3 & Biaya Overhead Variable & 114 \\
\hline \multicolumn{2}{|c|}{ Total } & $\mathbf{6 9 . 4 1 4}$ \\
\hline
\end{tabular}

$$
\begin{aligned}
\text { HPP per Unit } & =\frac{\text { Total Biaya }}{\text { Jumlah yang Diproduksi }} \\
& =\frac{\operatorname{Rp} 69.414}{4 \text { Liter }} \\
& =\operatorname{Rp} 17.353,5 / \text { Liter }
\end{aligned}
$$

Harga Jual =

Total Biaya + Laba yang diharapkan

Total Produksi

$=$

Rp $69.414+$ (20\% x Rp 69.414)

4 Liter

$=\frac{\operatorname{Rp} 69.414+\operatorname{Rp} 13.882,8}{4 \text { Liter }}$

$=\frac{\text { Rp 83.296,8 }}{4 \text { Liter }}$

$=\operatorname{Rp} 20.824,2$

$\approx \operatorname{Rp} 21.000 /$ Liter

Perhitungan Break Even Point (BEP)

Dalam menghitung Break Event Point ini diperlukan biaya tetap, biaya tetap yang digunakan pada pembuatan MOL yaitu biaya tenaga kerja dan depresiasi peralatan, peralatan yang digunakan yaitu blender. Perhitungan biaya depresiasi peralatan dan mesin digunakan rumus SLD (Straight Line Depresiation). Harga perolehan didapat dari harga produk, produk yang digunakan adalah blender dengan besaran harga $\mathrm{Rp}$ 310.000. Nilai residu adalah sisa suatu barang yang sudah habis nilai ekonominya, diasumsikan nilai residu pada blender sebesar $\mathrm{Rp}$ 50.000. Berikut ini perhitungan depresiasi mesin blender: 
Depresiasi Blender per Tahun

$$
\begin{aligned}
& =\frac{\text { Harga Perolehan }- \text { Nilai Residu }}{\text { Umur Kegunaan }} \\
& =\frac{\operatorname{Rp~} 310.000-\text { Rp 50.000 }}{3 \text { tahun }} \\
& =\frac{\operatorname{Rp~260.000}}{3 \text { tahun }} \\
& =\operatorname{Rp~} 86.667
\end{aligned}
$$

Rekapituasi biaya-biaya yang dikeluarkan pada pembuatan MOL dengan menggunakan metode variable

\begin{tabular}{|c|c|c|c|c|}
\hline No & \multicolumn{2}{|c|}{ Jenis Biaya } & $\begin{array}{l}\text { Harga } \\
\text { Perhari }\end{array}$ & $\begin{array}{c}\text { Harga } \\
\text { Pertahun }\end{array}$ \\
\hline \multirow{3}{*}{1} & \multirow{3}{*}{$\begin{array}{c}\text { Biaya } \\
\text { Variabel }\end{array}$} & $\begin{array}{c}\text { Biaya } \\
\text { Bahan } \\
\text { Baku } \\
\end{array}$ & 9.300 & 3.394 .500 \\
\hline & & $\begin{array}{c}\text { Biaya } \\
\text { Overhead } \\
\text { Variable }\end{array}$ & 114 & 41.610 \\
\hline & & Total & 9.414 & 3.436.110 \\
\hline \multirow{2}{*}{2} & \multirow{2}{*}{$\begin{array}{l}\text { Biaya } \\
\text { Tetap }\end{array}$} & $\begin{array}{c}\text { Biaya } \\
\text { Tenaga } \\
\text { Kerja }\end{array}$ & 60.000 & 21.900 .000 \\
\hline & & $\begin{array}{c}\text { Biaya } \\
\text { Deprisiasi } \\
\text { Peralatan }\end{array}$ & 237 & 86.667 \\
\hline & \multicolumn{2}{|c|}{ Total Keseluruhan } & 69.651 & 25.422.777 \\
\hline
\end{tabular}
costing:

Tabel 5. Rekapitulasi Biaya

Setelah biaya depresiasi peralatan didapat, maka selanjutnya menghitung Break Event Point. Untuk menghitung Break Event Point dapat digunakan rumus sebagai berikut:

$$
\underset{\text { Biaya Tetap }}{\mathrm{BEP} \text { (unit) }}=
$$

Harga per unit - variabel per unit

$$
\begin{aligned}
& =\frac{\operatorname{Rp~} 60.237}{\operatorname{Rp~} 17.353,5-\operatorname{Rp~} 2.353,5} \\
& =\frac{\operatorname{Rp~60.237}}{\operatorname{Rp~} 15.000} \\
& =4,0158 \text { Liter } \\
& \approx 4 \text { Liter }
\end{aligned}
$$

Catatan (jumlah perolehan biaya tetap dapat dilihat pada table 5, perhitungan untuk mendapatkan biaya variabel per unit adalah total biaya variabel di bagi dengan jumlah MOL yang di dapat, berarti total biaya variabel dibagi 4 ).

$$
\begin{aligned}
& \text { BEP (Rupiah) = } \\
& \text { Biaya Tetap } \\
& \text { 1-Biaya variabel/penjualan } \\
& \text { Rp } 60.237 \\
& 1 \text { - (Rp 9.414/Rp 69.414) } \\
& =\frac{\operatorname{Rp} 60.237}{\operatorname{Rp} 0,8644} \\
& =\operatorname{Rp} 69.686,49
\end{aligned}
$$

Catatan (jumlah perolehan biaya tetap sama dengan penjelasan di atas).

\section{KESIMPULAN}

Berdasarkan pengolahan data dilakukan sebelumnya, maka kesimpulan yang diperoleh adalah:

1. Pembuatan MOL dari limbah buah-buahan ini hampir sama dengan pembuatan MOL pada umumnya, namun di penelitian ini adanya variasi penambahan EM-4 serta limbah buah-buahan yang beragam. Berikut ini langkah proses pembuatan MOL dari limbah buah-buahan: proses penimbangan bahan, penghalusan bahan, pencampuran, pengadukan, dan penyimpanan.

2. Harga Pokok Produksi pada MOL yang didapatkan sebesar Rp 17.353,5/Liter atau dibulatkan $\mathrm{Rp}$ 17.000/liter dengan keuntungan margin sebesar $20 \%$ didapatkan harga jual sebesar Rp 20.824,2 atau dibulatkan Rp 21.000 dibanding dengan harga MOL dipasaran berkisar Rp 43.000/Liter, jadi harga jual MOL ini jauh lebih murah. BEP (Break Event Point) pada MOL dalam satuan unit adalah sebanyak 4 Liter dan dalam rupiah sebesar Rp 69.686,49.

\section{DAFTAR PUSTAKA}

Alnasser, N., Shaban, O. S., dan Al-Zubi, Z., 2014. The Effect of Using Break-EvenPoint in Planning, Controlling, and Decision Making in the Industrial 


\section{MUHAMMAD NUR, ALFINUR KHAIRI}

\section{Analisis Tekno Ekonomi Pemanfaatan Limbah Buah-Buahan Sebagai Mikro Organisme}

\section{Lokal (Mol)}

Jordanian Companies. International Journal of Academic Research in Business and Social Sciences, ISSN: 2222-6990, Vol. 4, No.5.

Bakhtiar, Syamsul Bahri, dan Darkasyi Mulyadi., 2012. Evaluasi Harga Pokok Produksi Untuk Menetapkan Harga Jual Dan Laba Produksi Pada Usaha Pabrik Batu Bata Di Desa Paloh Lada. Jurnal Teknik Industri, Vol. 1 No. 2, pp. 159173.

Carter, William K. 2009. Akuntansi Biaya. Jakarta: Salemba Empat.

Giatman, M. 2011. Ekonomi Teknik. Jakarta: PT. Rajagrafindo Persada.

Harjito, D Agus. 2012. Manajemen Keuangan. Yogyakarta: Kampus Fakultas Ekonomi Universitas Islam Indonesia.

Iskandar, Efendi dan Syamsu Rizal., 2011, Metode Depresiasi Aktiva Tetap Berwujud dan Dampaknya pada Laporan Laba Rugi. Jurnal Akuntansi \& Keuangan Vol 2 Nomor 1.

Jalaluddin, Nasrul ZA, Rizki Syafrina., 2016. Pengolahan Sampah Organik Buahbuahan Menjadi Pupuk Dengan Menggunakan Effective Microorganism. Jurnal Teknologi Kimia Unimal, 5.1: 17-29

Mindari, Wanti. 2018. Kesuburan Tanah dan Pupuk. Yogyakarta: Gosyen Publishing.

Nisa, Khalimatu Dkk. 2016. Memproduksi Kompos dan Mikro Organisme Lokal. Jakarta: Bibit Publisher.

Sabrin., 2015. Analisis Break Even Point Pada Produksi Es Balok. Jurnal Ekonomi Pembangunan FE-Unhalu Vol 16.

Setiadi, Pradana, David P.E. Saerang, dan Treesje Runtu., 2014. Perhitungan Harga Pokok Produksi Dalam Penentuan Harga Jual Pada CV. Minahasa Mantap Perkasa. Jurnal Berkala Ilmiah Efisiensi Vol. 14 No. 2.

Siska, Mery dan Rudy Salam., 2012. Desain Eksperimen Pengaruh Zeolit Terhadap
Penurunan Limbah Kadmium (Cd). Jurnal Ilmiah Teknik Industri, ISSN: 1412-6869, Vol. 11, No. 2.

Suhastyo, Arum Asriyanti, Iswandi Anas, Dwi Andreas Santosa, dan Yulin Lestari., 2013. Studi Mikrobiologi dan Sifat Kimia Mikro Organisme Lokal (MOL) yang Digunakan pada Padi Metode Sri. Jurnal Saintek, Vol. 10 No. 2.

Susetya, Darma. 2018. Panduan Lengkap Membuat Pupuk Organik. Yogyakarta: Pustaka Baru Press.

Thamrin, M, Susanto S, Susila AD, dan Sutandi A., 2013. Hubungan Konsentrasi Hara Nitrogen, Fosfor, dan Kalium Daun dengan Produksi Buah Sebelumnya Pada Tanaman Jeruk Pamelo. J. Hort. 23(3).

Waldiyono. 2008. Ekonomi Teknik. Yogyakarta: Pustaka Pelajar. 